\title{
The effect of rituximab therapy on immunoglobulin levels in patients with multisystem autoimmune disease
}

\author{
Helena Marco ${ }^{2 \dagger}$, Rona M Smith ${ }^{1 *+}$, Rachel B Jones ${ }^{1}$, Mary-Jane Guerry ${ }^{1}$, Fausta Catapano ${ }^{1}$, Stella Burns ${ }^{1}$,
} Afzal N Chaudhry ${ }^{1}$, Kenneth GC Smith ${ }^{1,3}$ and David RW Jayne ${ }^{1}$

\begin{abstract}
Background: Rituximab is a B cell depleting anti-CD20 monoclonal antibody. CD20 is not expressed on mature plasma cells and accordingly rituximab does not have immediate effects on immunoglobulin levels. However, after rituximab some patients develop hypogammaglobulinaemia.

Methods: We performed a single centre retrospective review of 177 patients with multisystem autoimmune disease receiving rituximab between 2002 and 2010. The incidence, severity and complications of hypogammaglobulinaemia were investigated.

Results: Median rituximab dose was $6 \mathrm{~g}$ (1-20.2) and total follow-up was 8012 patient-months. At first rituximab, the proportion of patients with $\operatorname{lgG}<6 \mathrm{~g} / \mathrm{L}$ was $13 \%$ and remained stable at $17 \%$ at 24 months and $14 \%$ at 60 months. Following rituximab, 61/177 patients (34\%) had lgG $<6 \mathrm{~g} / \mathrm{L}$ for at least three consecutive months, of whom 7/177 (4\%) had lgG $<3 \mathrm{~g} / \mathrm{L}$. Low immunoglobulin levels were associated with higher glucocorticoid doses during follow up and there was a trend for median lgG levels to fall after $\geq 6 \mathrm{~g}$ rituximab. 45/115 (39\%) with $\operatorname{lgG} \geq 6 \mathrm{~g} / \mathrm{L}$ versus $26 / 62$ (42\%) with $\operatorname{lgG}<6 \mathrm{~g} / \mathrm{L}$ experienced severe infections $(\mathrm{p}=0.750)$. 6/177 patients (3\%) received intravenous immunoglobulin replacement therapy, all with $\operatorname{lgG}<5 \mathrm{~g} / \mathrm{L}$ and recurrent infection.

Conclusions: In multi-system autoimmune disease, prior cyclophosphamide exposure and glucocorticoid therapy but not cumulative rituximab dose was associated with an increased incidence of hypogammaglobulinaemia. Severe infections were common but were not associated with immunoglobulin levels. Repeat dose rituximab therapy appears safe with judicious monitoring.
\end{abstract}

Keywords: Rituximab, Hypogammaglobulinaemia, B cell, Vasculitis, Systemic lupus erythematosus (SLE), IgG, Infection, Autoimmune

\section{Background}

Rituximab is increasingly used for multi-system autoimmune diseases, such as primary systemic vasculitis and systemic lupus erythematosus (SLE) [1-9]. Rituximab was licensed for the treatment of B cell lymphoma in 1997 [10], rheumatoid arthritis (RA) in 2006 [11-13] and ANCA associated vasculitis (AAV) in 2011.

Rituximab is a chimeric murine/human monoclonal antibody that results in complete peripheral blood B cell

\footnotetext{
* Correspondence: ronasmith@doctors.net.uk

${ }^{\dagger}$ Equal contributors

'Department of Medicine, School of Clinical Medicine, University of

Cambridge, Cambridge, UK

Full list of author information is available at the end of the article
}

depletion for variable time periods; typically 6-12 months. During B cell depletion, new vaccine responses are impaired and a theoretical risk of new infections exists [14]. However, since CD20 is highly expressed on B cells but not on stem cells or mature plasma cells, B cell regeneration from precursors is not directly compromised by rituximab and in the short term established humoral immunity is preserved; usually with stable levels of total IgG and established vaccination antibodies [14]. However, when rituximab is used in cohorts with high prior immunosuppressive exposure, where stem cell and plasma cell compartments maybe compromised, or when rituximab is administered long term using repeat dosing 
strategies resulting in prolonged B cell depletion, preexisting humoral immunity maybe impaired. Hypogammaglobulinaemia has occurred in more than 50\% of non-Hodgkin's lymphoma (NHL) patients, especially in those receiving rituximab in combination with chemotherapy or bone marrow transplantation [15-18], and less so in RA patients treated with rituximab where $3.5 \%$ had IgG levels below the normal range [19]. Hypogammaglobulinaemia has also been reported in small cohorts with primary systemic vasculitis treated with rituximab [20-23], although the impact of prior high immunosuppression exposure, and repeat rituximab dosing, as is widely used in clinical practice, are unclear.

Immunoglobulin plays a major role in adaptive immunity, and severe depletion of immunoglobulin, as observed in primary immunodeficiency syndromes increases infection risk [24]. The potential development of secondary immunodeficiency due to immunosuppressive medication, including the impact of prolonged B cell depletion on IgG levels and infection risk, is not well studied in patients with autoimmune disease.

We report on the frequency and severity of hypogammaglobulinaemia, and associated infection rates in a large cohort of rituximab treated patients with severe multisystem autoimmune diseases and prolonged follow-up.

\section{Methods}

This was a retrospective study conducted at Addenbrooke's Hospital, Cambridge, UK, which serves as a tertiary referral clinic and follows approximately 1000 patients with primary systemic vasculitis and SLE. In accordance with UK National Health Service Research Ethics Committee guidelines, ethical approval and patient consent were not required for this work because it comprises retrospective data and all treatment decisions were made prior to our evaluation.

All patients with multi-system autoimmune disease treated with rituximab between 2002 and 2010 were studied. 104 cases have previously been reported [3,5,25-27] and seven enrolled in a randomized controlled trial of rituximab [1] are also included in this cohort. Patients were excluded if they had fewer than six months followup or required repeated plasma exchange (PLEX).

\section{Clinical and laboratory assessments}

The data was collected retrospectively from patient notes and clinical databases. Data collection included pre-rituximab demographics, disease activity assessments, medications, adverse events and immunoglobulin levels at each clinical assessment.

\section{Dose of rituximab}

Rituximab induction therapy consisted of either $1000 \mathrm{mg}$ repeated after two weeks or $375 \mathrm{mg} / \mathrm{m}^{2} /$ week $\times 4$. Patients received further rituximab at the time of relapse or at 6 monthly intervals as a remission maintenance therapy.

\section{Disease activity}

AAV disease activity was graded by the Disease Extent Index (DEI score) [28] and by investigators' assessment of disease activity as either full remission (DEI $\leq 2$ and a steroid dose $\leq 10 \mathrm{mg}$ daily), partial remission (greater than $50 \%$ reduction in $\mathrm{DEI}$ ), ongoing disease/progressive disease (treatment failure), or relapse (increase in disease activity necessitating additional therapy beyond a temporary increase in glucocorticoid therapy).

SLE disease activity was graded by the BILAG disease activity (British Isles Lupus Assessment Group) and by investigators' assessment of disease activity as either full remission (absence of BILAG $\mathrm{A}, \mathrm{B}$ and $\mathrm{C}$ ), partial remission (absence of BILAG A and B), ongoing disease/ progressive disease (treatment failure), or relapse (increase in disease activity which required an increase in immunosuppressive therapy).

\section{Immunoglobulin levels}

IgG hypogammaglobulinaemia was defined by serum IgG $<6$ g/L (normal range 6.0-13.0 g/l) for at least three consecutive months at any point during follow-up, and classified as mild (5-5.9 g/L), moderate (3-4.9 g/L) and severe $(<3 \mathrm{~g} / \mathrm{L})$. IgM and IgA hypogammaglobulinaemia were defined by serum IgM levels $<0.4 \mathrm{~g} / \mathrm{L}$ (normal range $0.4-2.2 \mathrm{~g} / \mathrm{l}$ ) and IgA levels $<0.8 \mathrm{~g} / \mathrm{L}$ (normal range $0.8-3.7 \mathrm{~g} / \mathrm{l})$.

\section{Infections}

Infection was defined as severe when requiring hospitalisation and/or intravenous (IV) antibiotics.

\section{Statistical analysis}

Statistical analysis was performed using SPSS version 15 and GraphPad Prism version 5.01 (GraphPad Software, San Diego, CA). Results are expressed as values and proportions for categorical variables and medians and ranges for continuous variables. Clinical assessments and laboratory data were collected on a monthly basis. For missing values (e.g. if a patient did not attend clinic that month) a last value carried forward method was used until end of individual patient follow-up. The median interval between assessments was 3 months, with a median of 14 assessments per patient (1-55) and total patient follow-up of 8012 months. Changes in immunoglobulin levels over time were compared by a Wilcoxon signed rank test and between 2 groups by a Mann-Whitney $U$ test. Proportions of patients were compared using Fisher's exact test or Chi-squared test. Correlations were assessed using Spearman's rank correlation coefficient. Time to first severe infection was analysed using Kaplan-Meier survival 
analysis with log rank analysis for significance. A familywise $\mathrm{p}$ value $<0.05$ was considered significant for all statistical tests with appropriate adjustments being made for the multiple testing of serial data.

\section{Results \\ Patient characteristics}

One hundred and ninety-one patients received rituximab between 2002 and 2010. Fourteen were excluded; 10 due to less than six months follow-up and four due to repeated plasma exchange (PLEX). One hundred and seventy-seven patients were included (Table 1). The median age at first rituximab was 47 years (13-82); 31\% were male, and the majority had primary systemic vasculitis (56\%). Median disease duration before rituximab was 52 months (0-396) including 96\% with relapsing/refractory disease. The median number of prior immunosuppressive or immunomodulatory agents excluding glucocorticoids was three (0-14) including prior cyclophosphamide in 121/176 (69\%) with a median cumulative dose of $8 \mathrm{~g}(0-163)$. At time of first rituximab 72\% had active disease and $28 \%$ received rituximab for persistent low grade disease activity or as remission maintenance therapy when other drugs were contraindicated. Median follow up was 43 months (2-100). All patients had at least six months of follow-up, except for four who died within six months and were included in the analysis.

$118 / 177$ patients $(67 \%)$ received $2 \times 1000 \mathrm{mg}$ doses of rituximab two weeks apart and 54/177 (31\%), $375 \mathrm{mg} /$ $\mathrm{m}^{2} /$ week $\times 4$. Five did not complete the induction course. 152/177 (86\%) received further rituximab either for treatment of relapse or for remission maintenance. Median rituximab exposure was $6 \mathrm{~g}$ (1-20.2). Exposure adjusted for body surface area (BSA) was $3.3 \mathrm{~g} / \mathrm{m}^{2}(0.8$ 10.4), and BSA adjusted exposure/year was $1.1 \mathrm{~g} / \mathrm{m}^{2} /$ year (0.1-3.2) (for the 149 patients with BSA data available). The adjustment for BSA and time was necessary as 63/ 177 (36\%) patients received one or more BSA adjusted doses $\left(375 \mathrm{mg} / \mathrm{m}^{2} /\right.$ week $\left.\times 4\right)$ and follow-up duration was variable.

At time of first rituximab, 102/177 patients (58\%) were receiving other agents; 42/177 (24\%) cyclophosphamide, 28/177 (16\%) mycophenolate mofetil, 10/177 (6\%) hydroxychloroquine, 8/177 (5\%) azathioprine, 8/177 (5\%) methotrexate and $9 / 177$ (5\%) other agents. Of the 42 who received previous cyclophosphamide; 7/42 (17\%) were enrolled in a randomized controlled trial (RITUXVAS) [1] and received two doses of cyclophosphamide in accordance with the trial protocol.

\section{Disease response}

Rituximab was an effective therapy, with $151 / 171$ patients (88\%) achieving complete or partial remission by six months. Complete remission was seen in 117/171 (68\%) and partial remission in 34/171 (20\%). 20/171 (12\%) were considered treatment failures. There was no relationship between overall response (either complete or partial remission) and the presence or absence of hypogammaglobulinaemia ( $\operatorname{IgG}<6 \mathrm{~g} / \mathrm{l})$. In addition, no relationship was identified when complete and partial remission were considered independently, or when hypogammaglobulinaemia was sub-divided into moderate-severe (IgG $<5 \mathrm{~g} / \mathrm{l})$ or mild (IgG 5-6 g/l).

\section{Immunoglobulin}

\section{Frequency and severity of low immunoglobulin levels}

Immunoglobulin data was available for $136 / 177$ patients (77\%) at time of first rituximab treatment. 18/136 (13\%) had IgG hypogammaglobulinaemia ( $5 \%$ mild, $6 \%$ moderate and $2 \%$ severe). Of the 18 that initially had IgG hypogammaglobulinaemia, this was exacerbated in $13 / 18$ (72\%) following rituximab therapy. One experienced $>50 \%$ decrease in IgG level; 6 patients $>25 \%$ decrease and 4 patients $>10 \%$ decrease in IgG levels. At first rituximab, 14/136 (10\%) had IgM hypogammaglobulinaemia and 14/136 (10\%) had IgA hypogammaglobulinaemia (Table 2). Of the 118 patients who had IgG $>6 \mathrm{~g} / \mathrm{l}$ at time of first rituximab treatment, $27 / 118$ (23\%) subsequently went on to develop IgG hypogammaglobulinaemia, persisting for at least 3 consecutive months.

Following rituximab, 61/177 patients (34\%) had IgG hypogammaglobulinaemia, for at least three consecutive months at some point during follow-up. Of these, 18/177 (10\%) were mild, 36/177 (20\%) moderate and 7/177 (4\%) severe. After rituximab 90/177 patients (51\%) had IgM $<0.4 \mathrm{~g} / \mathrm{L}$ and $40 / 177$ (23\%) had $\operatorname{IgA}<0.8 \mathrm{~g} / \mathrm{L}$ (Table 2). During follow-up, the proportion of patients with IgG hypogammaglobulinaemia remained stable; $13 \%$ at time of first rituximab, $17 \%$ at 24 months and $14 \%$ at 60 months. Excluding those patients with hypogammaglobulinaemia at time of first rituximab, the median time to develop hypogammaglobulinaemia was 18 months (1-65), and median time to the hypogammaglobulinaemia category of maximum severity was 35 months (1-70).

\section{Median immunoglobulin levels}

Overall, median IgG levels remained relatively stable during follow-up, measuring at $9.3 \mathrm{~g} / \mathrm{L}$ at time of first rituximab, $8.4 \mathrm{~g} / \mathrm{L}$ at six months $(\mathrm{p}=0.388)$ and $8.25 \mathrm{~g} / \mathrm{L}$ at 60 months $(\mathrm{N}=52)(\mathrm{p}=0.140)$. IgM levels fell from $0.8 \mathrm{~g} / \mathrm{L}$ at time of first rituximab to $0.6 \mathrm{~g} / \mathrm{L}$ at six months $(\mathrm{p}<0.001)$ and $0.55 \mathrm{~g} / \mathrm{L}$ at 60 months $(\mathrm{p}<0.001)$. Baseline IgA levels were $1.9 \mathrm{~g} / \mathrm{L}, 1.6 \mathrm{~g} / \mathrm{L}$ at six months $(\mathrm{p}=$ $0.114)$ and $1.55 \mathrm{~g} / \mathrm{L}$ at 60 months $(\mathrm{p}=0.360)$ (Figure $1 \mathrm{~A})$. For those with $\operatorname{IgG}<6 \mathrm{~g} / \mathrm{L}(\mathrm{N}=18)$ at baseline, there was a trend for levels to increase, from a median of 
Table 1 Characteristics and treatments of patients receiving rituximab

\begin{tabular}{|c|c|}
\hline \multicolumn{2}{|l|}{ Baseline Characteristics $(\mathrm{N}=177)$} \\
\hline Age (years) at first rituximab & $47(13-82)$ \\
\hline Male sex & $54(31 \%)$ \\
\hline Diagnosis & $100(56 \%)$ \\
\hline Primary Systemic Vasculitis & $75(42 \%)$ \\
\hline Granulomatosis with polyangiitis (Wegener's) & $15(8 \%)$ \\
\hline Microscopic Polyangiitis & $10(6 \%)$ \\
\hline Churg Strauss Syndrome & $43(24 \%)$ \\
\hline Systemic lupus erythematosus & $3(2 \%)$ \\
\hline Behcet's disease & $3(2 \%)$ \\
\hline Henoch Schonlein Purpura & $28(16 \%)$ \\
\hline \multicolumn{2}{|l|}{ Other $^{\#}$} \\
\hline Prior disease duration (months) & $52(0-396)$ \\
\hline Prior cyclophosphamide $(\mathrm{N}=176)$ & $121(69 \%)$ \\
\hline Cumulative cyclophosphamide (g) $(\mathrm{N}=171)$ & $8(0-163)$ \\
\hline \multicolumn{2}{|l|}{ Prior therapies $(\mathrm{N}=176)$} \\
\hline Mycophenolate Mofetil & $123(70 \%)$ \\
\hline Azathioprine & $107(61 \%)$ \\
\hline Methotrexate & $46(26 \%)$ \\
\hline Intravenous immunoglobulin & $40(23 \%)$ \\
\hline Hydroxychloroquine & $29(16 \%)$ \\
\hline Anti-tumor necrosis factors agents & $26(15 \%)$ \\
\hline Plasma exchange & $26(15 \%)$ \\
\hline Alemtuzumab & $20(11 \%)$ \\
\hline Other $I S / \mathrm{IM}^{\$}$ & $63(36 \%)$ \\
\hline $\begin{array}{l}\text { Number of prior IS/IM agents (excluding steroids) } \\
(\mathrm{N}=176)\end{array}$ & $3(0-14)$ \\
\hline
\end{tabular}

$(\mathrm{N}=176)$

\begin{tabular}{ll}
\hline \multicolumn{2}{l}{ Patient characteristics at first rituximab infusion } \\
\hline Indication \\
\hline \multicolumn{1}{l}{ Active disease } & $127(72 \%)$ \\
\hline Consolidation of remission & $50(28 \%)$ \\
\hline Relapsing/refractory disease & $170(96 \%)$ \\
\hline New disease & $7(4 \%)$ \\
\hline Follow-up (months) & $43(2-100)$ \\
\hline Cyclophosphamide at time of rituximab & $42(24 \%)$ \\
\hline Rituximab total dose & $6(1-20.2)$ \\
\hline Total dose $(\mathrm{g})(\mathrm{N}=177)$ & $3.3(0.8-10.4)$ \\
\hline Dose/BSA $\left(\mathrm{g} / \mathrm{m}^{2}\right)(\mathrm{N}=149)$ & $1.1(0.1-3.2)$ \\
\hline Dose/BSA/year $\left(\mathrm{g} / \mathrm{m}^{2} / \mathrm{year}\right)(\mathrm{N}=149)$ &
\end{tabular}

Data are presented for 177 patients, unless otherwise stated. Results are expressed as either medians and ranges or numbers and proportions. All values reported at/from the time of first ever rituximab.

"other diagnoses include neurological autoimmune disease $(N=7)$, cryoglobulinaemia $(\mathrm{N}=3)$, urticarial vasculitis $(\mathrm{N}=3)$, polyarteritis nodosa $(\mathrm{N}=2)$, polychondritis $(\mathrm{N}=2)$, polymyositis $(\mathrm{N}=2)$, Takayasu's disease $(\mathrm{N}=1)$, membranous nephropathy $(\mathrm{N}=1)$, bullous pemphigoid $(\mathrm{N}=1)$ and unclassified autoimmune disease $(\mathrm{N}=6)$.

\$other IS/IM (immunosuppressant/immunomodulatory) agents include: ciclosporin ( $\mathrm{N}=15)$, gusperimus $(\mathrm{N}=13)$, tacrolimus $(\mathrm{N}=10)$, dapsone $(\mathrm{N}=4)$, leflunomide $(\mathrm{N}=4)$, sirolimus $(\mathrm{N}=3)$, antithymocyte globulin $(\mathrm{N}=2)$, colchicine $(N=2)$, gold $(N=2)$, abatacept $(N=1)$, mefloquine $(N=1)$, other $(N=6)$. BSA - body surface area.
$4.3 \mathrm{~g} / \mathrm{L}$ at time of first rituximab to $4.7 \mathrm{~g} / \mathrm{L}$ at six months $(\mathrm{p}=0.276)$ and $6.4 \mathrm{~g} / \mathrm{L}$ at 60 months $(\mathrm{N}=7)(\mathrm{p}=0.099)$ (Figure 1B).

\section{Effect of prior cyclophosphamide treatment on IgG levels} $121 / 176$ patients (69\%) received prior cyclophosphamide treatment. 46/121 (38\%) who received prior cyclophosphamide and 16/55 (29\%) who did not, developed IgG hypogammaglobulinaemia $(p=0.308)$. In patients who received prior cyclophosphamide median IgG levels were lower at time of first rituximab $(8.85 \mathrm{~g} / \mathrm{L}$ vs. $10.4 \mathrm{~g} / \mathrm{L})(\mathrm{p}=0.025)$ but not at 60 months $(7.9 \mathrm{~g} / \mathrm{L}$ vs. $9.7 \mathrm{~g} / \mathrm{L})(\mathrm{p}=0.138)(\mathrm{N}=51)$.

\section{Effect of dose of rituximab on IgG levels}

$39 / 79$ (49\%) who received $<6$ g rituximab and 32/98 (33\%) who received $\geq 6$ g rituximab developed IgG hypogammaglobulinaemia for at least 3 months $(\mathrm{p}=0.527)$. Patients who received $<6 \mathrm{~g}$ of rituximab had stable IgG levels during follow-up with a median of $8.5 \mathrm{~g} / \mathrm{L}$ at time of first rituximab, $8.1 \mathrm{~g} / \mathrm{L}$ at six months $(\mathrm{p}=0.204)$ and $8.7 \mathrm{~g} / \mathrm{L}$ at 60 months $(\mathrm{N}=21)(\mathrm{p}=0.178)$. In patients who received $\geq 6$ g rituximab, IgG levels trended downward from a median of $9.8 \mathrm{~g} / \mathrm{L}$ at time of first rituximab to $9.3 \mathrm{~g} / \mathrm{L}$ at six months $(\mathrm{p}=0.989)$ and to $7.5 \mathrm{~g} / \mathrm{L}$ at 60 months $(\mathrm{N}=31)(\mathrm{p}=0.381)$ (Figure $1 \mathrm{C})$.

\section{Effect of glucocorticoid exposure on IgG levels}

Median cumulative oral prednisolone exposure following the first rituximab infusion was $7.25 \mathrm{~g}(0-54.5)$. There was a negative correlation $(r=-0.17(\mathrm{CI}-0.31$ to -0.02$)$ $\mathrm{p}=0.02$ ) between total oral prednisolone exposure after initial rituximab and IgG levels. Data on cumulative glucocorticoid exposure prior to rituximab therapy was unavailable. 57/177 (32\%) received at least one dose of intravenous methylprednisolone following rituximab. Of those that received intravenous methylprednisolone $49 \%$ (28/57) developed hypogammaglobulinaemia compared to $28 \%(34 / 120)$ of those that did not $(\mathrm{p}=0.011)$.

\section{Effect of disease diagnosis on IgG levels}

$56 \%$ of patients in this cohort had primary systemic vasculitis; $24 \%$ SLE and 20\% other autoimmune conditions. There was no association between diagnosis and the development of IgG hypogammaglobulinaemia (Chi-square = $3.24 ; \mathrm{df}=2 ; \mathrm{p}=0.198)$.

\section{Severe hypogammaglobulinaemia}

$7 / 177$ patients (4\%) had IgG $<3 \mathrm{~g} / \mathrm{L}$ for at least three consecutive months during follow-up. The median age at first rituximab dose was 46 years (16-54), diagnoses were primary systemic vasculitis $(\mathrm{N}=5)$, and $\operatorname{SLE}(\mathrm{N}=2)$. Median disease duration before rituximab was 57 months (8-360). The median number of immunosuppressive or immunomodulatory agents received excluding 
Table 2 Frequency and severity of low immunoglobulin levels

\begin{tabular}{|c|c|c|c|c|c|c|}
\hline & \multicolumn{4}{|c|}{$\lg G$} & \multirow{3}{*}{$\begin{array}{c}\operatorname{lgM} \\
<0.4 \mathrm{~g} / \mathrm{L}\end{array}$} & \multirow{3}{*}{$\begin{array}{c}\lg A \\
<0.8 \mathrm{~g} / \mathrm{L}\end{array}$} \\
\hline & $<6 \mathrm{~g} / \mathrm{L}$ & Mild & Moderate & $\overline{\text { Severe }}$ & & \\
\hline & & $5-5.9 \mathrm{~g} / \mathrm{L}$ & $3-4.9 \mathrm{~g} / \mathrm{L}$ & $<3 \mathrm{~g} / \mathrm{L}$ & & \\
\hline Baseline hypogammaglobulinaemia & $18(13 \%)$ & $6(5 \%)$ & $9(6 \%)$ & $3(2 \%)$ & $14(10 \%)$ & $14(10 \%)$ \\
\hline Hypogammaglobulinaemia & $61(34 \%)$ & $18(10 \%)$ & $36(20 \%)$ & $7(4 \%)$ & $90(51 \%)$ & $40(23 \%)$ \\
\hline
\end{tabular}

Baseline hypogammaglobulinaemia $(\mathrm{N}=136)$ : total number and proportion in parentheses of patients with low immunoglobulin levels at time of first rituximab. Hypogammaglobulinaemia ( $\mathrm{N}=177)$ : total number and proportion in parentheses of patients with low immunoglobulin levels following rituximab for at least three consecutive months at some point during follow-up.

glucocorticoids was 3 [2-7] including prior cyclophosphamide in $5 / 7$ patients (71\%). Median rituximab exposure was $5.6 \mathrm{~g}(2-7.9)$. Two required intravenous immunoglobulin (IVIg) as replacement, 9 and 37 months after rituximab, due to recurrent infections. Four had $\operatorname{IgG}<3 \mathrm{~g} / \mathrm{L}$ during the first six months, 3/4 (75\%) had proteinuria $\geq 3$ g/day with IgG levels rising with better disease control.

\section{Adverse events}

\section{Severe infections}

One hundred and seventy severe infections occurred in 71/177 patients (40\%) during 8012 patient-months. Annual incidence rates of infection were 21.5 cases per 100 patient years in year $1 ; 10.9$ in year 2; 5.2 in year 3; 1.9 in year 4 and 2.5 in year 5 . The time to first severe infection was not different according to IgG levels (Figure 2).
Ninety (53\%) were chest infections, 26 (15\%) urinary tract infections, 12 (7\%) diarrhoeal illnesses (stool culture positive), seven (4\%) skin infections and 35 (21\%) other infections. Seven opportunistic infections were reported in six patients; three, with granulomatosis with polyangiitis and severe cavitating lung disease had pulmonary aspergillosis (one with chronic aspergillosis diagnosed before rituximab); $2 / 3$ patients had moderate hypogammaglobulinaemia including the patient with chronic aspergillosis who required IVIg replacement; two had infection with herpes zoster, one with moderate hypogammaglobulinaemia; and one without hypogammaglobulinaemia had both reactivation of Cytomegalovirus (CMV) and infection with Mycobacterium avian intracellulari. No cases of Hepatitis B reactivation or progressive multifocal leukoencephalopathy (PML) were reported.
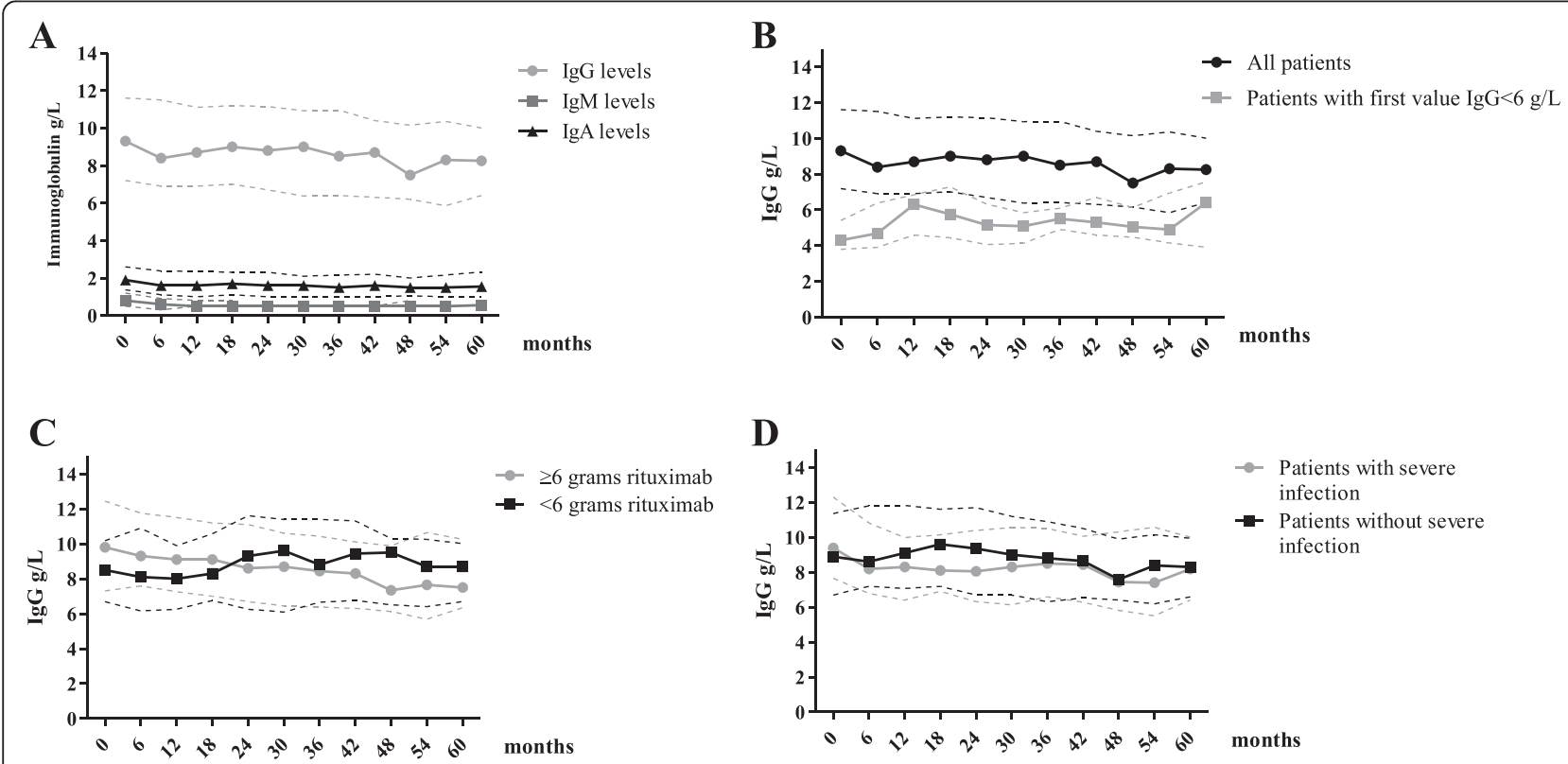

D

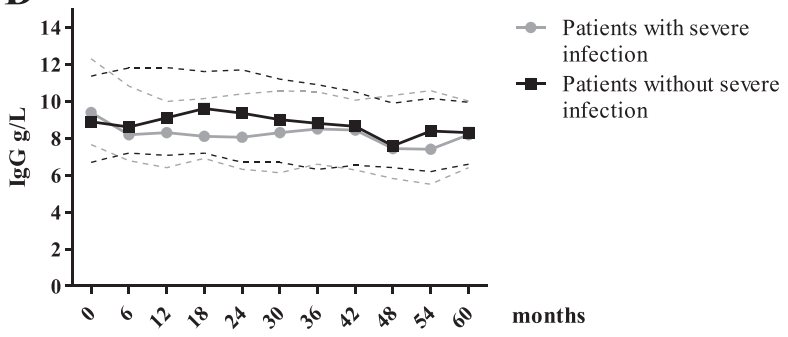

Figure 1 The effect of rituximab on median immunoglobulin levels. Median immunoglobulin levels are represented as a continuous line and interquartile ranges as dashed lines, according to time after first rituximab treatment, from 0 to 60 months. A. IgG, IgM and IgA levels for all 177 patients. B. Comparison of IgG levels for all patients with those patients with $\operatorname{lgG}<6 \mathrm{~g} / \mathrm{L}$ before first rituximab ( $\mathrm{N}=18)$. C. Comparison of lgG levels for patients who received $<6 \mathrm{~g}$ of rituximab in total $(\mathrm{N}=79)$ and patients who received $\geq 6 \mathrm{~g}$ of rituximab $(\mathrm{N}=98)$. D. Comparison of lgG levels for patients with $(N=71)$ and without $(N=106)$ severe infection. 


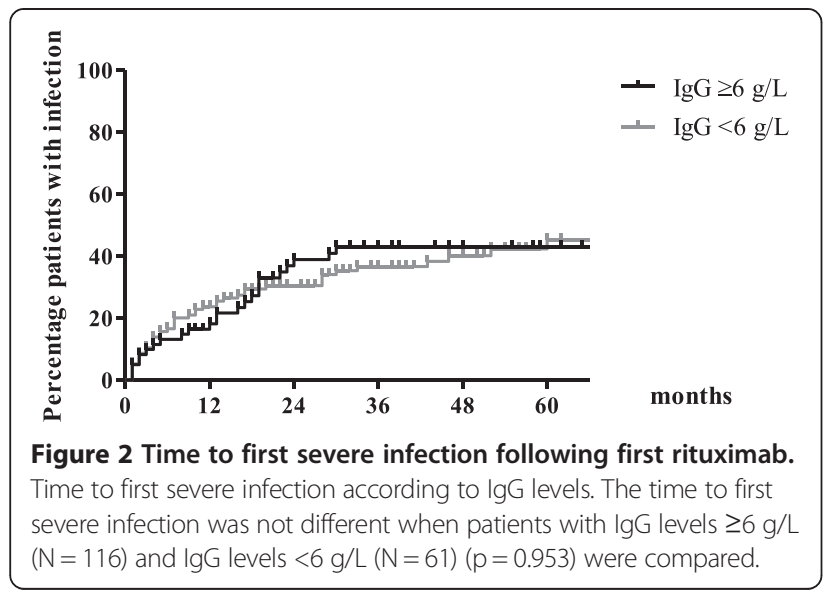

45/115 patients (39\%) with $\operatorname{IgG} \geq 6 \mathrm{~g} / \mathrm{L}$ and $26 / 62$ (42\%) with IgG $<6 \mathrm{~g} / \mathrm{L}$ experienced severe infections $(\mathrm{p}=0.750)$ (Table 3$) .43$ severe infections occurred in $17 / 36$ patients $(47 \%)$ with moderate and eight in $2 / 7$ patients (29\%) with severe hypogammaglobulinaemia. There were no differences in median overall IgG levels between patients with and without infection (Figure 1D). Fourteen severe infections occurred in $7 / 18$ (39\%) with baseline IgG $<6 \mathrm{~g} / \mathrm{L}$ and 95 occurred in 44/118 (37\%) with baseline IgG $\geq 6 \mathrm{~g} / \mathrm{L}(\mathrm{p}=1.00)$. There was no difference in the proportion of patients affected by infection according IgM and IgA levels (Table 3).

There was a positive correlation $(r=0.265$, (CI 0.118 to 0.401$)(\mathrm{p}<0.001))$ between cumulative oral prednisolone exposure and the occurrence of infection. However, no correlation was seen between risk of infection and cumulative rituximab exposure $(\mathrm{r}=-0.093(\mathrm{CI}-0.242$ to -0.060$)(\mathrm{p}=0.217)$ or prior cumulative cyclophosphamide exposure $(r=0.084$ ( $(\mathrm{CI}-0.072$ to 0.235$)(\mathrm{p}=0.276)$.

\section{Need for IVIg}

6/177 patients (3\%) received IVIg as replacement. Median age at first rituximab was 43 years (16-67); median

Table 3 Severe infections according to immunoglobulin subtype and levels

\begin{tabular}{ccc}
\hline & $\begin{array}{c}\text { Normal immunoglobulin } \\
\text { levels }\end{array}$ & $\begin{array}{c}\text { Low immunoglobulin } \\
\text { levels }\end{array}$ \\
\hline IgG & $\mathbf{2 6} \mathbf{~ g / L}$ & $<\mathbf{6 ~ g / L}$ \\
Patients affected & $45 / 115(39 \%)$ & $26 / 62(42 \%)$ \\
IgM & $\geq \mathbf{0 . 4} \mathbf{~ g / L}$ & $<\mathbf{0 . 4} \mathbf{~ g / L}$ \\
Patients affected & $32 / 87(37 \%)$ & $39 / 90(43 \%)$ \\
IgA & $\geq \mathbf{0 . 8} \mathbf{~ g / L}$ & $<\mathbf{0 . 8} \mathbf{~ g / L}$ \\
Patients affected & $56 / 137(41 \%)$ & $15 / 40(38 \%)$ \\
\hline
\end{tabular}

The number and proportion of patients suffering severe infections according immunoglobulin subtype (lgG, $\lg M$ and $\lg A)$ and immunoglobulin level are presented. There is no difference in the proportion of patients affected by infection when comparing lgG levels $\geq 6 \mathrm{~g} / \mathrm{L}$ and $<6 \mathrm{~g} / \mathrm{L}(\mathrm{p}=0.750)$; IgM levels $\geq 0.4 \mathrm{~g} / \mathrm{L}$ and $<0.4 \mathrm{~g} / \mathrm{L}(\mathrm{p}=0.6)$ and $\lg A$ levels $\geq 0.8 \mathrm{~g} / \mathrm{L}$ and $<0.8 \mathrm{~g} / \mathrm{L}(\mathrm{p}=0.855)$. rituximab exposure was $5.9 \mathrm{~g}$ (4-11.1). The median time from first rituximab treatment to start of replacement was 18.5 months [4-37]. The median IgG level before first rituximab was $4.8 \mathrm{~g} / \mathrm{L}$ (4.4-5.8) and IgG level before first IVIg was $3.9 \mathrm{~g} / \mathrm{L}$ (3.1-4.8). All patients had recurrent infections despite antibiotic prophylaxis and 5/6 had chronic lung disease.

\section{Deaths}

Thirteen patients (4 SLE, 6 primary systemic vasculitis, 3 other autoimmune diseases) died. The median age at first rituximab treatment was 62 years $(43-82)$. Causes of death were: respiratory failure $(\mathrm{n}=2$ at 10 and 28 months after first rituximab) both with pre-existing pulmonary fibrosis; infection $(\mathrm{n}=4$ at $4,15,49$ and 84 months) one with peritonitis, two with sepsis and active SLE with chronic kidney disease, and one with chest sepsis with chronic kidney disease and ischemic heart disease; myocardial infarction ( $\mathrm{n}=1$, at 47 months), malignancy ( $\mathrm{n}=2$ at 27 and 31 months); unknown cause $(\mathrm{n}=4$ at $2,3,5$ and 16 months). $2 / 13$ patients (15\%) had mild hypogammaglobulinaemia and 3/13 (23\%) moderate hypogammaglobulinaemia.

\section{Discussion}

Rituximab is an effective therapy for remission induction in patients with multi-system autoimmune disease [1,2,26,29]. However, the majority of patients will relapse after a single course [3,5]. Further courses are effective, although concerns surround the long term effect on humoral immunity and infection risk with repeated rituximab use [30,31]. Rituximab depletes $\mathrm{CD} 20+\mathrm{B}$ cells for an average of 6-12 months. Mature plasma cells (the source of $95 \%$ of circulating IgG) do not express CD20; however, prolonged depletion of plasma cell precursors may reduce replenishment of mature plasma cells leading to hypogammaglobulinaemia and infection risk.

We studied the frequency and severity of hypogammaglobulinaemia and severe infections following repeated rituximab dosing in patients with multi-system autoimmune disease. Low IgG, IgM and IgA levels were more frequent before first rituximab $(13 \%, 10 \%$ and $10 \%$ of patients respectively) than in NHL or RA [16,17,32-34]. At 60 months, the proportion of patients with low IgG remained stable $(14 \%)$ however, those with low IgM or IgA rose to $25 \%(\mathrm{p}=0.018)$ and $17 \%(\mathrm{p}=0.211)$ respectively. The increase in proportion of patients with $\operatorname{IgM}<0.4 \mathrm{~g} / \mathrm{L}$ following rituximab, is consistent with previous data in SLE and AAV patients [3,20-23,26]. Low levels of IgG, IgM and IgA occurred in $34 \%, 51 \%$ and $23 \%$ of patients for at least 3 consecutive months at any time during follow-up. In keeping with the overall stabile proportion of patients with low IgG during follow-up, the majority of episodes of IgG hypogammaglobulinaemia were mild or 
transient, and only a minority suffered moderate/severe prolonged IgG hypogammaglobulinaemia. IgG levels were lower at baseline in patients who had received prior cyclophosphamide treatment. However, the development of IgG hypogammaglobulinaemia was not associated with prior cyclophosphamide exposure, but was associated with a higher cumulative corticosteroid exposure during follow-up. Median IgG levels trended downwards in those who received $>6 \mathrm{~g}$ rituximab, although this did not reach statistical significance.

Our study is retrospective and whilst it does represent real life event rates of hypogammaglobulinaemia and severe infections, in patients with complex multisystem autoimmune disease treated with rituximab, outcomes are confounded by clinical strategies to reduce infection risk, and concomitant therapies that contribute to hypogammaglobulinaemia and infection risk. In our practice repeat rituximab dosing is used to treat and prevent disease flare irrespective of peripheral blood B cell count. Immunoglobulins are monitored at each clinic visit. Concomitant immunosuppressive therapies are generally not used alongside rituximab and during follow-up corticosteroids are reduced or withdrawn. In patients with repeated infections, antibiotic prophylaxis is employed; and in patients with infections despite antibiotics and moderate/severe hypogammaglobulinaemia ( $\operatorname{IgG}<5 \mathrm{~g} / \mathrm{l}$ ), IVIG replacement is used. Discontinuation of further rituximab dosing is considered in patients with $\operatorname{IgG}<5 \mathrm{~g} / \mathrm{l}$ with a downward (rather than stable) trajectory and recurrent infections; however, this decision is balanced against ongoing disease activity, the efficacy benefit derived from rituximab and the availability of other therapeutic options.

Existing data supports the safety of repeated doses of rituximab in RA and NHL, where stable infection rates were observed following initiation of rituximab treatment $[33,35,36]$. We observed infections in $38 \%$ of patients in the first year of treatment; similar to rates seen in other studies in primary systemic vasculitis $[1,2,37,38]$ where active disease, chronic lung and kidney disease, prior cyclophosphamide and high corticosteroid exposure also contribute to infection risk. As in RA and NHL, the occurrence of persistent mild hypogammaglobulinaemia (IgG 5-6 g/l) following rituximab was not associated with a higher infection rate $[33,35,36]$. Unlike other populations, where IgG levels $<5$ g/l have been associated with infection risk [34], we did not observe an association; however, regular monitoring, antibiotic prophylaxis and IVIG replacement may have reduced infection rates in this subgroup.

Overall we observed a reduction in severe infection rates over time, along with improved disease control, a minimisation of corticosteroids and avoidance of concomitant immunosuppression. Our data suggest that provided careful monitoring is employed together with judicious use of prophylactic therapies, the IgM hypogammaglobulinaemia, transient mild/moderate IgG hypogammaglobulinaemia or occasional severe IgG hypogammaglobulinaemia observed with repeat rituximab dosing are not dominant factors in infection risk in a severe multisystem autoimmune disease population.

\section{Conclusion}

We have reported on the frequency and severity of hypogammaglobulinaemia and potential infective complications following rituximab therapy in a large retrospective survey of patients with multi-system autoimmune disease with long term follow-up. Following rituximab treatment the proportion of patients with IgM and IgA hypogammaglobulinaemia rose, but the proportion with IgG hypogammaglobulinaemia remained stable. The risk of IgG hypogammaglobulinaemia was not increased by low baseline immunoglobulin levels or prior cyclophosphamide therapy or greater cumulative rituximab exposure. However, patients with high concomitant glucocorticoid doses were at risk of developing IgG hypogammaglobulinaemia.

Only a small minority developed severe IgG hypogammaglobulinaemia necessitating IVIG replacement. Severe infections were frequent in this patient population and were associated with higher glucocorticoid exposure but were not associated with IgG levels. Overall, rituximab was a safe therapy in this population. Regular immunoglobulin monitoring is indicated with repeat rituximab dosing to identify the small minority of patients with progressively falling IgG levels.

\section{Competing interests}

Dr. Jayne has received research grant support for investigator initiated studies from Roche. Dr. Jayne and Dr. Chaudhry have received consulting fees from Roche. Dr. Jayne, Dr Jones, Dr. Smith and Dr. Chaudhry have received lecture fees from Roche. Dr. Chaudhry has received travel expenses from Roche

\section{Authors' contributions}

HM, RS and RJ contributed to study design, acquisition of data, analysis of data, interpretation of the results and drafting the manuscript. MJG, FC and SB were involved in data acquisition. AC assisted with statistical analysis. DJ was involved with study design, interpretation of the results and critical review of the manuscript. KS and AC provided critical review of the manuscript. All authors read and approved the final manuscript.

\section{Authors' information}

$\mathrm{HM}$ and RS are joint first authors. They have contributed equally to the study design, acquisition of data, analysis of data, interpretation of the results and drafting the manuscript.

\section{Acknowledgements}

This work was supported by the NIHR Cambridge Biomedical Research Centre and Dr Marco was supported by ERA-EDTA (long-term fellowship). We thank all the nurses and physicians involved in the care of the patients included in this study.

\section{Author details}

${ }^{1}$ Department of Medicine, School of Clinical Medicine, University of Cambridge, Cambridge, UK. ${ }^{2}$ Nephrology Division, Fundació Puivert, 
Universitat Autònoma de Barcelona, Barcelona, Spain. Currently working on Nephrology Division, Germans Trias I Pujol, Badalona, Spain. ${ }^{3}$ Cambridge Institute for Medical Research, Cambridge Biomedical Campus, Cambridge, UK.

Received: 23 January 2014 Accepted: 15 May 2014 Published: 25 May 2014

\section{References}

1. Jones RB, Tervaert JW, Hauser T, Luqmani R, Morgan MD, Peh CA, Savage CO, Segelmark M, Tesar V, van Paassen P, Walsh D, Walsh M, Westman K, Jayne DR, European Vasculitis Study Group: Rituximab versus cyclophosphamide in ANCA-associated renal vasculitis. N Engl J Med 2010, 363(3):211-220. PubMed PMID: 20647198.

2. Stone JH, Merkel PA, Spiera R, Seo P, Langford CA, Hoffman GS, Kallenberg CG, St Clair EW, Turkiewicz A, Tchao NK, Webber L, Ding L, Sejismundo LP, Mieras K, Weitzenkamp D, Ikle D, Seyfert-Margolis V, Mueller M, Brunetta P, Allen NB, Fervenza FC, Geetha D, Keogh KA, Kissin EY, Monach PA, Peikert T, Stegeman C, Ytterberg SR, Specks U, RAVE-ITN Research Group: Rituximab versus cyclophosphamide for ANCA-associated vasculitis. N Engl J Med 2010 363(3):221-232. PubMed PMID: 20647199. Pubmed Central PMCID: 3137658.

3. Jones RB, Ferraro AJ, Chaudhry AN, Brogan P, Salama AD, Smith KG, Savage $\mathrm{CO}$, Jayne DR: A multicenter survey of rituximab therapy for refractory antineutrophil cytoplasmic antibody-associated vasculitis. Arthritis Rheum 2009, 60(7):2156-2168. PubMed PMID: 19565480

4. Guerry MJ, Brogan P, Bruce IN, D'Cruz DP, Harper L, Luqmani R, Pusey CD, Salama AD, Scott DG, Savage CO, Watts RA, Jayne DR: Recommendations for the use of rituximab in anti-neutrophil cytoplasm antibody-associated vasculitis. Rheumatology 2012, 51(4):634-643. PubMed PMID: 21613248

5. Smith RM, Jones RB, Guerry MJ, Laurino S, Catapano F, Chaudhry A, Smith $K G$, Jayne DR: Rituximab for remission maintenance in relapsing antineutrophil cytoplasmic antibody-associated vasculitis. Arthritis Rheum 2012, 64(11):3760-3769. PubMed PMID: 22729997.

6. Cartin-Ceba R, Golbin JM, Keogh KA, Peikert T, Sanchez-Menendez M, Ytterberg SR, Fervenza FC, Specks U: Rituximab for remission induction and maintenance in refractory granulomatosis with polyangiitis (Wegener's): ten-year experience at a single center. Arthritis Rheum 2012. 64(11):3770-3778. PubMed PMID: 22730028.

7. Merrill JT, Neuwelt CM, Wallace DJ, Shanahan JC, Latinis KM, Oates JC, Utset TO, Gordon C, Isenberg DA, Hseih HJ, Zhang D, Brunetta PG: Efficacy and safety of rituximab in moderately-to-severely active systemic lupus erythematosus: the randomized, double-blind, phase II/III systemic lupus erythematosus evaluation of rituximab trial. Arthritis Rheum 2010, 62(1):222-233. PubMed PMID: 20039413

8. Rovin BH, Furie R, Latinis K, Looney RJ, Fervenza FC, Sanchez-Guerrero J, Maciuca R, Zhang D, Garg JP, Brunetta P, Appel G, LUNAR Investigator Group: Efficacy and safety of rituximab in patients with active proliferative lupus nephritis: the Lupus Nephritis Assessment with Rituximab study. Arthritis Rheum 2012, 64(4):1215-1226. PubMed PMID: 22231479.

9. Smith RM, Clatworthy MR, Jayne DR: Biological therapy for lupus nephritis-tribulations and trials. Nat Rev Rheumatol 2010, 6(9):547-552 PubMed PMID: 20647994

10. McLaughlin P, Grillo-Lopez AJ, Link BK, Levy R, Czuczman MS, Williams ME, Heyman MR, Bence-Bruckler I, White CA, Cabanillas F, Jain V, Ho AD, Lister J, Wey K, Shen D, Dallaire BK: Rituximab chimeric anti-CD20 monoclonal antibody therapy for relapsed indolent lymphoma: half of patients respond to a four-dose treatment program. J Clin Oncol 1998 16(8):2825-2833. PubMed PMID: 9704735.

11. Edwards JC, Szczepanski L, Szechinski J, Filipowicz-Sosnowska A, Emery P, Close DR, Stevens RM, Shaw T: Efficacy of B-cell-targeted therapy with rituximab in patients with rheumatoid arthritis. N Engl I Med 2004, 350(25):2572-2581. PubMed PMID: 15201414.

12. Cohen SB, Emery P, Greenwald MW, Dougados M, Furie RA, Genovese MC, Keystone EC, Loveless JE, Burmester GR, Cravets MW, Hessey EW, Shaw T, Totoritis MC, REFLEX Trial Group: Rituximab for rheumatoid arthritis refractory to anti-tumor necrosis factor therapy: Results of a multicenter, randomized, double-blind, placebo-controlled, phase III trial evaluating primary efficacy and safety at twenty-four weeks. Arthritis Rheum 2006, 54(9):2793-2806. PubMed PMID: 16947627.

13. Emery P, Fleischmann R, Filipowicz-Sosnowska A, Schechtman J, Szczepanski L, Kavanaugh A, Racewicz AJ, van Vollenhoven RF, Li NF, Agarwal S, Hessey
EW, Shaw TM, DANCER Study Group: The efficacy and safety of rituximab in patients with active rheumatoid arthritis despite methotrexate treatment: results of a phase IIB randomized, double-blind, placebo-controlled, dose-ranging trial. Arthritis Rheum 2006 54(5):1390-1400. PubMed PMID: 16649186.

14. Eisenberg RA, Jawad AF, Boyer J, Maurer K, McDonald K, Prak ET, Sullivan KE: Rituximab-treated patients have a poor response to influenza vaccination. J Clin Immunol 2013, 33(2):388-396. PubMed PMID: 23064976 Pubmed Central PMCID: 3565069.

15. Lim SH, Zhang Y, Wang Z, Esler W, Beggs D, Pruitt B, Hancock P, Townsend M: Maintenance rituximab after autologous stem cell transplant for high-risk B-cell lymphoma induces prolonged and severe hypogammaglobulinemia. Bone Marrow Transplant 2005, 35(2):207-208. PubMed PMID: 15531902

16. Nishio M, Fujimoto K, Yamamoto $S$, Endo T, Sakai T, Obara M, Kumano $K$, Minauchi K, Yamaguchi K, Takeda Y, Sato N, Koizumi K, Mukai M, Koike T: Hypogammaglobulinemia with a selective delayed recovery in memory $B$ cells and an impaired isotype expression after rituximab administration as an adjuvant to autologous stem cell transplantation for non-Hodgkin lymphoma. Eur J Haematol 2006, 77(3):226-232. PubMed PMID: 16923109

17. Hicks LK, Woods A, Buckstein R, Mangel J, Pennell N, Zhang L, Imrie K, Spaner D, Cheung MC, Boudreau A, Reis M, Crump M, Berinstein NL: Rituximab purging and maintenance combined with auto-SCT: long-term molecular remissions and prolonged hypogammaglobulinemia in relapsed follicular lymphoma. Bone Marrow Transplant 2009, 43(9):701-708. PubMed PMID: 19029963

18. Irie E, Shirota Y, Suzuki C, Tajima Y, Ishizawa K, Kameoka J, Harigae H, Ishii T: Severe hypogammaglobulinemia persisting for 6 years after treatment with rituximab combined chemotherapy due to arrest of B lymphocyte differentiation together with alteration of T lymphocyte homeostasis. Int J Hematol 2010, 91(3):501-508. PubMed PMID: 20217285.

19. van Vollenhoven RF, Emery P, Bingham CO 3rd, Keystone EC, Fleischmann RM, Furst DE, Tyson N, Collinson N, Lehane PB: Long-term safety of rituximab in rheumatoid arthritis: 9.5-year follow-up of the global clinical trial programme with a focus on adverse events of interest in RA patients. Ann Rheum Dis 2013, 72(9):1496-1502. PubMed PMID: 23136242.

20. Keogh KA, Ytterberg SR, Fervenza FC, Carlson KA, Schroeder DR, Specks U: Rituximab for refractory Wegener's granulomatosis: report of a prospective, open-label pilot trial. Am J Respir Crit Care Med 2006, 173(2):180-187. PubMed PMID: 16224107. Pubmed Central PMCID: 2662987.

21. Rees F, Yazdani R, Lanyon P: Long-term follow-up of different refractory systemic vasculitides treated with rituximab. Clin Rheumatol 2011, 30(9):1241-1245. PubMed PMID: 21523362

22. Venhoff $N$, Effelsberg NM, Salzer U, Warnatz K, Peter HH, Lebrecht D, Schlesier M, Voll RE, Thiel J: Impact of rituximab on immunoglobulin concentrations and $B$ cell numbers after cyclophosphamide treatment in patients with ANCA-associated vasculitides. PLoS One 2012, 7(5):e37626. PubMed PMID: 22629432. Pubmed Central PMCID: 3357389.

23. Holle JU, Dubrau C, Herlyn K, Heller M, Ambrosch P, Noelle B, Reinhold-Keller $E$, Gross WL: Rituximab for refractory granulomatosis with polyangiitis (Wegener's granulomatosis): comparison of efficacy in granulomatous versus vasculitic manifestations. Ann Rheum Dis 2012, 71(3):327-333. PubMed PMID: 22021864

24. Furst DE: Serum immunoglobulins and risk of infection: how low can you go? Semin Arthritis Rheum 2009, 39(1):18-29. PubMed PMID: 18620738.

25. Smith $K G$, Jones RB, Burns SM, Jayne DR: Long-term comparison of rituximab treatment for refractory systemic lupus erythematosus and vasculitis: Remission, relapse, and re-treatment. Arthritis Rheum 2006, 54(9):2970-2982. PubMed PMID: 16947528

26. Catapano F, Chaudhry AN, Jones RB, Smith KG, Jayne DW: Long-term efficacy and safety of rituximab in refractory and relapsing systemic lupus erythematosus. Nephrol Dial Transplant 2010, 25(11):3586-3592. PubMed PMID: 20466686

27. Martinez Del Pero M, Chaudhry A, Jones RB, Sivasothy P, Jani P, Jayne D: B-cell depletion with rituximab for refractory head and neck Wegener's granulomatosis: a cohort study. Clin Otolaryngol 2009, 34(4):328-335. PubMed PMID: 19673980

28. de Groot K, Gross WL, Herlyn K, Reinhold-Keller E: Development and validation of a disease extent index for Wegener's granulomatosis. Clin Nephrol 2001, 55(1):31-38. PubMed PMID: 11200865. 
29. Terrier B, Amoura Z, Ravaud P, Hachulla E, Jouenne R, Combe B, Bonnet C, Cacoub P, Cantagrel A, de Bandt M, Fain O, Fautrel B, Gaudin P, Godeau B, Harlé JR, Hot A, Kahn JE, Lambotte O, Larroche C, Léone J, Meyer O, Pallot-Prades B, Pertuiset E, Quartier P, Schaerverbeke T, Sibilia J, Somogyi A, Soubrier M, Vignon E, Bader-Meunier B, et al: Safety and efficacy of rituximab in systemic lupus erythematosus: results from 136 patients from the French Autolmmunity and Rituximab registry. Arthritis Rheum 2010, 62(8):2458-2466. PubMed PMID: 20506527.

30. Casulo C, Maragulia J, Zelenetz AD: Incidence of hypogammaglobulinemia in patients receiving rituximab and the use of intravenous immunoglobulin for recurrent infections. Clin Lymphoma Myeloma Leuk 2013, 13(2):106-111. PubMed PMID: 23276889

31. Roubaud-Baudron C, Pagnoux C, Meaux-Ruault N, Grasland A, Zoulim A, LE Guen J, Prud'homme A, Bienvenu B, de Menthon M, Camps S, LE Guern V, Aouba A, Cohen P, Mouthon L, Guillevin L, French Vasculitis Study Group: Rituximab maintenance therapy for granulomatosis with polyangiitis and microscopic polyangiitis. J Rheumato/ 2012, 39(1):125-130. PubMed PMID: 22089465

32. Lim SH, Zhang Y, Wang Z, Varadarajan R, Periman P, Esler WV: Rituximab administration following autologous stem cell transplantation for multiple myeloma is associated with severe IgM deficiency. Blood 2004, 103(5):1971-1972. PubMed PMID: 14976066

33. van Vollenhoven RF, Emery P, Bingham CO 3rd, Keystone EC, Fleischmann R, Furst DE, Macey K, Sweetser M, Kelman A, Rao R: Longterm safety of patients receiving rituximab in rheumatoid arthritis clinical trials. J Rheumatol 2010, 37(3):558-567. PubMed PMID: 20110520.

34. Gottenberg JE, Ravaud P, Bardin T, Cacoub P, Cantagrel A, Combe B, Dougados M, Flipo RM, Godeau B, Guillevin L, Le Loët X, Hachulla E, Schaeverbeke T, Sibilia J, Baron G, Mariette X, Autolmmunity and Rituximab registry and French Society of Rheumatology: Risk factors for severe infections in patients with rheumatoid arthritis treated with rituximab in the autoimmunity and rituximab registry. Arthritis Rheum 2010, 62(9):2625-2632. PubMed PMID: 20506353.

35. van Oers MH, Klasa R, Marcus RE, Wolf M, Kimby E, Gascoyne RD, Jack A, Van't Veer M, Vranovsky A, Holte H, van Glabbeke M, Teodorovic I, Rozewicz C, Hagenbeek A: Rituximab maintenance improves clinical outcome of relapsed/resistant follicular non-Hodgkin lymphoma in patients both with and without rituximab during induction: results of a prospective randomized phase 3 intergroup trial. Blood 2006, 108(10):3295-3301. PubMed PMID: 16873669.

36. Keystone E, Fleischmann R, Emery P, Furst DE, van Vollenhoven R, Bathon J, Dougados M, Baldassare A, Ferraccioli G, Chubick A, Udell J, Cravets MW, Agarwal S, Cooper S, Magrini F: Safety and efficacy of additional courses of rituximab in patients with active rheumatoid arthritis: an open-label extension analysis. Arthritis Rheum 2007, 56(12):3896-3908. PubMed PMID: 18050221

37. Walsh M, Chaudhry A, Jayne D: Long-term follow-up of relapsing/refractory anti-neutrophil cytoplasm antibody associated vasculitis treated with the lymphocyte depleting antibody alemtuzumab (CAMPATH-1H). Ann Rheum Dis 2008, 67(9):1322-1327. PubMed PMID: 18055469.

38. Flossmann O, Baslund B, Bruchfeld A, Tervaert JW, Hall C, Heinzel P, Hellmich B, Luqmani RA, Nemoto K, Tesar V, Jayne DR: Deoxyspergualin in relapsing and refractory Wegener's granulomatosis. Ann Rheum Dis 2009 68(7):1125-1130. PubMed PMID: 18713783

\section{Submit your next manuscript to BioMed Central and take full advantage of:}

- Convenient online submission

- Thorough peer review

- No space constraints or color figure charges

- Immediate publication on acceptance

- Inclusion in PubMed, CAS, Scopus and Google Scholar

- Research which is freely available for redistribution

Submit your manuscript at www.biomedcentral.com/submit
C) Biomed Central 